\title{
THE STATE OF THE ART IN LEAN MANUFACTURING
}

\author{
Vujica Herzog, N.; PAlcic, I. \& Polajnar, A.
}

Abstract: The main purpose of the paper is to present the state of the art in Lean Manufacturing with the instructions for future research. Lean manufacturing (LM), firstly developed by Taiichi Ohno at Toyota Motor Company in the 1950s, is a conceptual framework popularized in many Western industrial companies since the early 1990s. The main potential of LM is the ability to improve the company's competitiveness. To achieve this purpose, the primary goal of LM is cost reduction or improvement of productivity through responsiveness to change and waste minimization.

The literature review shows the need for inclusion of other modern concepts, such as Lean Manufacturing together with e.g. Six-Sigma or Theory of Constrains. In a broader company level the incorporation of the appropriate management accounting system is the necessity for the successful implementation of organizational strategy through the lean principles.

Key words: Lean Manufacturing, Value stream mapping, Six-Sigma, Theory of Constrains
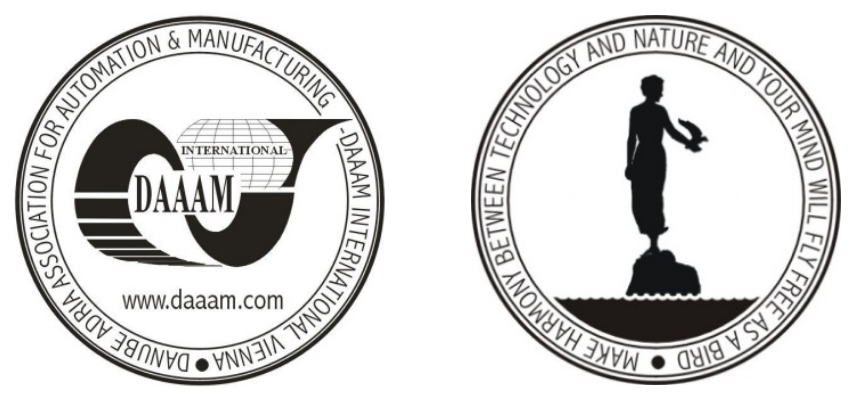

Authors' data: Dr. Ass.Prof. Herzog, N[atasa] V[ujica]; Ass. Prof. Palcic, I[ztok]; Prof. Dr. Polajnar, A[ndrej], University of Maribor, Smetanova ulica 17, 2000, Maribor, SI, natasa.vujica@uni-mb.si, iztok.palcic@uni-mb.si, andrej.polajnar@unimb.si

This Publication has to be referred as: Vujica Herzog, N[atasa]; Palcic, I[ztok] \& Polajnar, A[ndrej] (2008). The State of the Art in Lean Manufacturing, Chapter 80 in DAAAM International Scientific Book 2008, pp. 967-976, B. Katalinic (Ed.), Published by DAAAM International, ISBN 978-3-901509-66-7, ISSN 1726-9687, Vienna, Austria

DOI: $10.2507 /$ daaam.scibook.2008.80 